\title{
STRATEGI PENGEMBANGAN EKOWISATA DI PUSAT INFORMASI MANGROVE (PIM) KELURAHAN KANDANG PANJANG PEKALONGAN
}

\author{
Strategy of Ecotourism Development in the Mangrove Information Center (PIM) of \\ Kandang Panjang Urban Village Pekalongan
}

Elok Faiqoh, Siti Rudiyanti*, Frida Purwanti

\author{
Program Studi Manajemen Sumberdaya Perairan, Jurusan Perikanan \\ Fakultas Perikanan dan Ilmu Kelautan, Universitas Diponegoro \\ Jl. Prof. Soedarto, SH, Tembalang, Semarang, Jawa Tengah - 50275, Telp/Fax. +6224 7474698 \\ Email : elokfaiqoh012@gmail.com
}

\begin{abstract}
ABSTRAK
Kawasan ekowisata di Pusat Informasi Mangrove (PIM) merupakan salah satu wisata alam di Kota Pekalongan yang berpotensi untuk dikembangkan. Tujuan penelitian untuk mengetahui potensi daya tarik, profil pengunjung, persepsi, partisipasi, aspirasi pengunjung dan masyarakat dalam pengembangan ekowisata serta merumuskan strategi pengembangan ekowisata. Penelitian dilakukan pada Maret 2018. Metode yang digunakan adalah survey dengan menggunakan kuesioner yang disebarkan kepada 91 responden pengunjung, 30 masyarakat dan 2 pengelola. Teknik pengambilan sampel pengunjung dengan accidental sampling, untuk masyarakat dan pengelola dengan purposive sampling. Pembobotan kuesioner dengan skala Likert, penentuan strategi menggunakan SWOT. Potensi daya tarik meliputi: keanekaragaman jenis mangrove; asosiasi biota meliputi ikan bandeng, kakap putih, mujaer, udang Vaname dan kepiting bakau; fasilitas yang tersedia meliputi: boat, shelter pemancingan, jogging track, Gedung PRPM, Shelter, lahan parkir, kamar mandi, menara pandang dan mushola; aksesibilitas (kondisi jalan beraspal, dilengkapi petunjuk arah). Persepsi pengunjung dan masyarakat mengenai daya tarik dan aksesibilitas tergolong baik, namun persepsi mengenai fasilitas tergolong kurang baik. Partisipasi pengunjung dan masyarakat dalam menjaga lingkungan tergolong baik. Aspirasi pengunjung dan masyarakat mengenai pengadaan fasilitas pelengkap. Strategi pengembangan ekowisata di PIM meliputi: pengembangan ekowisata dengan konsep pelestarian ekosistem serta melakukan koordinasi dengan Pemerintah Daerah; peningkatan pemberdayaan masyarakat sekitar dalam mengoptimalkan fasilitas kawasan ekowisata; menjaga ekosistem mangrove dengan cara mengefektifkan rehabilitas dan penegakan peraturan perlindungan mangtrove; dan meningkatkan fasilitas/sarana prasarana yang dapat digunakan untuk meminimalkan dampak dari abrasi.
\end{abstract}

Kata Kunci : Pekalongan, Strategi Pengembangan, Ekowisata, SWOT

\section{ABSTRACT}

Ecotourism area in the Mangrove Information Center (PIM) is one of the nature tourism in Pekalongan City that potential to be developed. The purpose of this research were to know the attraction potency, visitor profile, perception, participation, aspiration of visitor and community in ecotourism development as well as to set an ecotourism development strategy. This research was conducted in March 2018. The method used a survey using a questionnaire distibuted to 91 visitors, 30 communities and 2 managements staff. Sampling technique for visitor used accidental sampling, for community and management staff used purposive sampling. Questionnaire weighted by Likert scale, strategy determinated by SWOT. The attraction potency include: diversity of mangroves; biota association include milkfish, seabass, mujaer, Vaname shrimp and crab; available facilities include: passenger boats, fishing shelters, jogging tracks, PRPM building, shelters, parking lots, bathroom, view tower and small mosque; accessibility (directed paved road). The perception of visitors and community about attractiveness and accessibility were quite good, but the perception of facility was not good enough. Participation of respondents in maintaining the environment was good. Aspirations of the visitors and community toward development was procurement of facilities. Development strategy of ecotourism in PIM include: development of ecotourism with ecosystem preservation concept as well as coordination with local goverments; increased empowerment of local communities in optimizing ecotourism facilities area; keep the mangrove ecosystem by rehabilition effectiveness and enforcement protection mangrove regulation; and improve the facilities/infrastructure that can be used to minimize the impact of abrasion.

Keywords: Pekalongan; Development Strategy; Ecotourism; SWOT

*) Penulis penanggungjawab 


\section{Pendahuluan}

Wilayah Kota Pekalongan merupakan wilayah di Pantai Utara Jawa yang berbatasan langsung dengan Laut Jawa. Kota Pekalongan secara geografis memiliki letak yang strategis karena berada di jalan pantai utara, selain itu juga memiliki berbagai macam obyek wisata, baik wisata religi, wisata budaya maupun wisata alam. Pusat Informasi Mangrove (PIM) terletak di Kelurahan Kandang Panjang, pada awalnya (tahun 1980an) PIM merupakan lahan tambak yang digunakan untuk budidaya udang windu, namun pada tahun 1990an tambak udang windu tersebut tidak produktif sehingga tidak dikelola kembali. Mengetahui hal tersebut, Pemerintah Daerah Kota Pekalongan membebaskan lahan tambak untuk dimanfaatkan sebagai lahan penanaman mangrove. Kegiatan penanaman mangrove tersebut dapat menarik wisatawan untuk berkunjung sehingga kawasan tersebut saat ini dikembangkan menjadi kawasan ekowisata yang berbasis edukasi.

Pemanfaatan ekosistem mangrove untuk ekowisata sejalan dengan pergeseran minat wisatawan yaitu dari old tourism atau wisatawan yang hanya datang melakukan kegiatan wisata saja tanpa adanya unsur pendidikan dan konservasi menjadi new tourism atau wisatawan yang datang untuk melakukan kegiatan wisata yang didalamnya terdapat unsur pendidikan dan konservasi (Agussalim dan Hartoni, 2014).

Ekowisata merupakan suatu bentuk perjalanan wisata yang bertanggung jawab ke kawasan alami yang dilakukan dengan tujuan mengkonservasi lingkungan, melestarikan kehidupan dan kesejahteraan penduduk setempat. Ekowisata dapat dilihat sebagai suatu konsep pengembangan pariwisata berkelanjutan yang bertujuan untuk mendukung upaya-upaya pelestarian lingkungan dan meningkatkan partisipasi masyarakat dalam pengelolaannya (Saifullah dan Harahap, 2013). Ekowisata mangrove di PIM sangat cocok dijadikan sebagai salah satu daerah tujuan wisata keluarga. Ekowisata di PIM dapat digunakan sebagai sarana pengenalan tanaman mangrove kepada anak-anak dengan kegiatan penanaman mangrove untuk berbagai usia. Fasilitas yang dapat dinikmati saat berkunjung ke tempat ini ialah lahan parkir, fasilitas edukasi berupa galeri ekosistem hutan mangrove dan kolam sentuh (kolam edukasi pembibitan dan penanaman mangrove), perpustakaan dan ruang diskusi, shelter (gazebo apung), jogging track, dan gedung pusat restorasi pembelajaran mangrove.

Pengembangan kawasan ekosistem mangrove menjadi salah satu kawasan ekowisata merupakan salah satu cara untuk mencegah meluasnya kerusakan ekosistem mangrove, mengingat pentingnya ekosistem mangrove bagi keberlangsungan mahluk hidup. Oleh karena itu diperlukan identifikasi dalam penyusunan strategi pengembangan ekowisata yang dapat digunakan untuk pengembangan kawasan ekowisata yang berkelanjutan. Selain itu, dalam menyusun strategi pengembangan kawasan ekowisata harus tetap memperhatikan konsep ekowisata yang berkelanjutan. Pengembangan ekowisata berkelanjutan adalah pengembangan yang dapat didukung secara ekologis sekaligus layak secara ekonomi, dan adil secara etika dan sosial terhadap masyarakat. Artinya pengembangan berkelanjutan adalah upaya terpadu dan terorganisasi untuk mengembangkan kualitas hidup dengan cara mengatur penyediaan, pengembangan, pemanfaatan dan pemeliharaan sumberdaya secara berkelanjutan (Haryanto, 2014).

Tujuan dari penelitian ini adalah untuk mengetahui potensi yang menjadi daya tarik wisata, mengetahui persepsi, partisipasi, aspirasi responden dalam pengembangan ekowisata dan menyusun strategi pengembangan ekowisata di PIM Pekalongan.

\section{MATERI DAN METODE PENELITIAN}

\section{A. Materi Penelitian}

Materi yang digunakan dalam penelitian ini adalah potensi ekowisata di PIM Pekalongan dan tanggapan pengunjung dan masyarakat mengenai persepsi, partisipasi dan aspirasi dalam pengembangan ekowisata di PIM Pekalongan. Alat yang digunakan dalam penelitian ini adalah kuesioner sebagai pedoman untuk kegiatan wawancara, alat tulis untuk mencatat hasil wawancara, dan kamera untuk dokumentasi.

\section{B. Metode Penelitian}

Metode yang digunakan dalam penelitian ini adalah metode survey. Menurut Sugiyono (2013) metode survey digunakan untuk mendapatkan data dari tempat tertentu yang alamiah (bukan buatan), tetapi peneliti melakukan perlakuan dalam pengumpulan data, misalnya dengan mengedarkan kuesioner, test, wawancara terstruktur dan sebagainya (perlakuan tidak seperti dalam ekperimen).

Jenis dan sumber data dalam penelitian ini yaitu dengan menggunakan data primer dan data sekunder. Cara pengumpulan data primer yaitu dengan kegiatan wawancara dengan bantuan kuisioner kepada responden. Data sekunder didapatkan dari berbagai Dinas/Instansi-Instansi seperti: Dinas Pariwisata Kebudayaan Kepemudaan dan Olahraga Kota Pekalongan, Dinas Lingkungan Hidup Kota Pekalongan, Dinas Perikanan dan Kelautan Kota Pekalongan, serta Kantor Kelurahan Kandang Panjang Kec. Pekalongan Utara Kota Pekalongan.

Penentuan responden pengunjung dengan teknik accidential sampling yaitu teknik penentuan sampel berdasarkan kebetulan, yaitu siapa saja yang secara kebetulan bertemu dengan peneliti dapat digunakan sebagai sampel (Sugiyono, 2012). Penentuan jumlah sampel responden untuk pengunjung yaitu menggunakan metode Slovin yang didasarkan pada rata-rata jumlah pengunjung kawasan ekowisata dengan derajat kecermatan $10 \%$. Perhitungan sampel pengunjung pada penelitian ini adalah: 


$$
\begin{aligned}
\mathrm{n} & =\frac{\mathrm{N}}{\mathrm{Nd}^{2}+1} \\
& =\frac{1000}{1000(0,1)^{2}+1} \\
& =\frac{1000}{11}=90,9 \rightarrow 91 \text { Responden }
\end{aligned}
$$

Responden masyarakat merupakan masyarakat yang terlibat langsung dalam kegiatan pengelolaan kawasan ekowisata di PIM Pekalongan. Penentuan responden masyarakat dengan teknik purposive sampling yaitu teknik pengambilan sampel sumber data dengan pertimbangan tertentu, misalnya orang tersebut dianggap paling tahu tentang apa yang kita harapkan (Sugiyono, 2013).

Analisis data yang digunakan untuk menganalisis daya tarik wisata, persepsi, partisipasi, dan aspirasi responden dalam pengembangan ekowisata mangrove di Kelurahan Panjang yaitu dengan menggunakan skala Likert. Menurut Sugiyono (2013) skala Likert digunakan untuk mengukur sikap, pendapat, dan persepsi seseorang atau sekelompok orang mengenai fenomena sosial.

Analisis SWOT adalah analisis kondisi internal maupun eksternal yang selanjutnya akan digunakan sebagai dasar untuk merancang strategi. Analisis internal meliputi penilaian terhadap faktor kekuatan (Strength) dan kelemahan (Weakness). Analisis eksternal mencakup faktor peluang (Opportunity) dan ancaman (Threat). Hal pertama yang dilakukan dalam menentukan matriks SWOT adalah mengetahui faktor strategi internal (IFAS) dan faktor strategi eksternal (EFAS). Penentuan berbagai faktor, bobot setiap faktor dan tingkat kepentingan setiap faktor didapatkan dari hasil wawancara dengan responden yang berkompeten dibidangnya dan disesuaikan dengan kondisi di lapangan. Setelah seluruh data terkumpul, tahap selanjutnya yaitu menentukan faktor strategi internal dan eksternal dari masing-masing jawaban dari pertanyaan yang diajukan. Faktor strategi internal adalah sebagai berikut:

1. Menentukan faktor-faktor yang menjadi kekuatan dan kelemahan dari kegiatan pengelolaan.

2. Memberi bobot pada masing-masing faktor kekuatan dan kelemahan. Jumlah seluruh bobot harus sebesar 1,00 .

3. Menghitung rating untuk masing-masing faktor kekuatan dan kelemahan berdasarkan pengaruh/respon faktor-faktor tersebut terhadap pengembangan.

4. Mengalikan bobot dengan rating untuk memperoleh skor. Hasil dari perkalian ini berupa skor pembobotan untuk masing-masing faktor kekuatan dan kelemahan.

Faktor strategi eksternal adalah sebagai berikut:

1. Menentukan faktor-faktor yang menjadi peluang serta ancaman dari kegiatan pengelolaan.

2. Memberi bobot pada masing-masing faktor sesuai dengan tingkat kepentingan. Jumlah seluruh bobot harus sebesar 1,00 .

3. Menghitung rating untuk masing-masing faktor berdasarkan pengaruh/respon faktor-faktor tersebut terhadap pengembangan.

4. Mengalikan bobot dengan rating untuk memperoleh skor. Hasil dari perkalian ini berupa skor pembobotan untuk masing-masing faktor.

Setelah matriks IFAS dan EFAS selesai, selanjutnya unsur-unsur tersebut dihubungkan dalam matrik untuk memperoleh beberapa alternatif strategi. Matriks ini memungkinkan empat kemungkinan strategi.

Tabel 1. Diagram Matriks SWOT

\begin{tabular}{|l|c|c|}
\hline EFAS & $\begin{array}{c}\text { STRENGTHS (S) } \\
\text { Tentukan faktor kekuatan internal }\end{array}$ & $\begin{array}{c}\text { WEAKNESSES (W) } \\
\text { Tentukan faktor kelemahan } \\
\text { internal }\end{array}$ \\
\hline $\begin{array}{l}\text { OPPORTUNITIES (O) } \\
\text { Tentukan faktor peluang eksternal }\end{array}$ & $\begin{array}{c}\text { Strategi S-O } \\
\text { (Strategi menggunakan kekuatan } \\
\text { untuk memanfaatkan peluang) }\end{array}$ & $\begin{array}{c}\text { Strategi W-O } \\
\text { (Strategi meminimalkan } \\
\text { kelemahan untuk memanfaatkan } \\
\text { peluang) }\end{array}$ \\
$\begin{array}{l}\text { THREATS (T) } \\
\text { eksternal }\end{array}$ & $\begin{array}{c}\text { Strategi S-T } \\
\text { (Strategi menggunakan kekuatan } \\
\text { untuk mengatasi ancaman) }\end{array}$ & $\begin{array}{c}\text { Strategi W-T } \\
\text { (Strategi meminimalkan } \\
\text { kelemahan untuk menghindari } \\
\text { ancaman) }\end{array}$ \\
\hline
\end{tabular}

Penentuan prioritas strategi dilakukan dengan memperhatikan faktor-faktor yang saling terkait dalam penelitian. Jumlah dari skor pembobotan menentukan ranking prioritas strategi dalam pengembangan ekowisata 
mangrove di PIM Kelurahan Kandang Panjang. Jumlah skor diperoleh dari penjumlahan semua skor di setiap faktor-faktor strategi yang terkait. Ranking akan ditentukan berdasarkan urutan jumlah skor terbesar sampai yang terkecil dari semua strategi yang ada.

\section{HASIL DAN PEMBAHASAN}

\section{Kondisi Umum Lokasi Penelitian}

Ekowisata di PIM terletak di Kecamatan Pekalongan Utara tepatnya di Kelurahan Kandang Panjang. Luas wilayah Kelurahan Kandang Panjang yaitu 150.150 Ha. Secara administratif Kelurahan Kandang Panjang memiliki batas-batas wilayah yaitu: Sebelah utara: Laut Jawa; Sebelah selatan: Kelurahan Dukuh; Sebelah barat: Kelurahan Bandengan; dan Sebelah timur: Kelurahan Panjang Wetan dan Panjang Baru. Jarak Kelurahan Kandang Panjang dari Pusat Pemerintahan Kecamatan yaitu 0, 50 km, jarak ke Ibukota Kabupaten Kota yaitu 8 $\mathrm{km}$ dan jarak ke Ibukota Provinsi yaitu $102 \mathrm{~km}$. Jumlah penduduk di Kelurahan Kandang Panjang sebanyak 13.713 jiwa, yang terdiri dari 6.248 jiwa dengan jenis kelamin laki-laki, dan 7.465 jiwa dengan jenis kelamin perempuan.

\section{Potensi Daya Tarik Ekowisata \\ Keanekaragaman Mangrove}

Keanekaragaman mangrove merupakan salah satu potensi yang menjadi daya tarik pengunjung untuk berkunjung ke kawasan ekowisata yang terletak di PIM Kelurahan Kandang Panjang, Pekalongan. Mangrove merupakan kumpulan jenis pohon/tanaman yang dapat tumbuh di pesisir yang toleran terhadap kadar garam tinggi. Keanekaragaman mangrove dan asosiasi mangrove yang ada di Kawasan Ekowisata di PIM Pekalongan disajikan pada Tabel 2.

Tabel 2. Keanekaragaman dan Asosiasi Mangrove di Kawasan Ekowisata di PIM Pekalongan

\begin{tabular}{lll}
\hline Jenis & Spesies & Nama Lokal \\
\hline Mangrove Sejati & & Api-api \\
Avicennia & Avicennia alba & Api-api \\
& A. lanata marina & Api-api \\
Bruguiera & Bruguiera gymnorrhiza & Lindur \\
Nypa & Nypa friticans & Nipah \\
Rhizophora & Rhizophora lamarckii & Bakau \\
& R. mucronata & Bakau \\
Sonneratia & R. stylosa & Bakau \\
& Sonneratia alba & Pidada/bogem \\
Xyocarpus & S. caseolaris & Pidada/bogem \\
\hline Asosiasi Mangrove & Xylocarpus granatum & Nyiri \\
Acanthus & & \\
Carbera & Acanthus ilicifolius & Jeruju \\
Derris & Carbera manghas & Bintaro \\
Hibiscus & Derris trifoliata & Tuba laut \\
Scaevola & Hibiscus tiliaceus & Waru laut \\
Stachytarpheta & Scaevola taccada & Bakung-bakung \\
\hline
\end{tabular}

\section{Asosiasi Biota}

Biota yang tumbuh di kawasan ekowisata yang ada di PIM Kelurahan kandang Panjang yaitu ikan, udang dan kepiting.Sebagian besar ikan hidup bebas di kawasan ekosistem mangrove, sehingga menyebabkan banyaknya pengunjung yang datang ke ekowisata untuk menyalurkan hobi memancing. Kawasan ekowisata yang ada di PIM juga menyediakan shelter pemancingan/spot pemancingan bagi pengunjung yang ingin menyalurkan hobinya.

Ekosistem mangrove pada umumnya merupakan habitat bagi berbagai jenis biota, baik itu biota laut maupun biota terestrial diantaranya berbagai jenis burung, reptil, serta invertebrata. Hal tersebut dikarenakan ekosistem mangrove merupakan salah satu ekosistem pesisir yang memiliki fungsi ekologis sebagai tempat pembesaran, perlindungan dan mencari makan bagi biota (Chadijah et al., 2013).

\section{Fasilitas/Sarana Prasarana}

Fasilitas/sarana prasarana yang ada di PIM Pekalongan meliputi: boat/kapal penumpang, digunakan untuk melakukan perjalanan wisata untuk menyusuri lorong mangrove; jogging track, merupakan jalur bagi pengunjung untuk dapat menikmati pemandangan kawasan ekowisata mangrove; shelter, digunakan untuk tempat berlindung/beristirahat para pengunjung; shelter pemancingan, merupakan spot pemancingan yang 
dibangun untuk pengunjung yang ingin menyalurkan hobi memancing; Gedung PRPM/PIM, merupakan gedung yang digunakan sebagai tempat penyuluhan pembelajaran serta sebagai pusat informasi bagi pengunjung; lahan parkir, sarana yang disediakan untukpemenuhan kebutuhan parkir; kamar mandi, digunakan untuk sarana MCK bagi pengunjung; menara pandang, merupakan sarana untuk melihat ataupun mengawasi mangrove; mushola, untuk melaksanakan ibadah bagi pengunjung; dan tempat pembibitan permanen dan semi permanen, merupakan tempat praktik pembibitan untuk kelompok pecinta lingkungan (pelajar, mahasiswa maupun masyarakat umum).

Peranan sarana dan prasarana untuk memudahkan pengunjung dalam menikmati potensi dan daya tarik wisata alam. Sarana merupakan salah satu faktor penunjang yang memudahkan pengunjung dalam menikmati objek wisata secara langsung (Rosadi et al., 2015).

\section{Aksesibilitas}

Akses menuju kawasan ekowisata di PIM Pekalongan sangatlah mudah karena telah dilengkapi oleh petunjuk arah yang telah dipasang di beberapa titik sehingga memudahkan pengunjung untuk dapat menemukan lokasi ekowisata. Selain itu untuk menuju ekowisata mangrove di PIM juga telah didukung oleh kondisi jalan yang bagus, sehingga memudahkan pengunjung untuk mengakses jalan. Kemudahan aksesibilitas merupakan salah satu hal penting yang harus diperhatikan, apabila aksesibilitas mudah maka akan meningkatkan jumlah pengunjung di kawasan ekowisata di PIM Pekalongan.

Aksesibilitas merupakan syarat penting untuk mempermudah pengunjung berkunjung ke suatu tempat objek wisata. Syarat yang diperlukan dalam melakukan kunjungan ke suatu objek wisata yaitu jarak yang dekat, kondisi jalan menuju objek wisata, tipe jalan, dan waktu yang diperlukan dari pusat kota (Simanjuntak et al., 2016).

\section{Persepsi, Partisipasi dan Aspirasi \\ Persepsi Pengunjung dan Masyarakat}

Persepsi merupakan proses yang digunakan seorang individu untuk memilih, mengorganisasikan, dan menginterprstasi masukan-masukan informasi guna menciptakan gambaran dunia yang memiliki arti, persepsi tidak hanya tergantung pada rangsangan fisik, tetapi juga pada rangsangan yang berhubungan dengan lingkungan sekitar dan keadaan individu yang bersangkutan (Murianto, 2014).

\section{Persepsi terhadap Daya Tarik Ekowisata}

Menurut Undang-Undang No. 10 tahun 2009 tentang kepariwisataan, daya tarik wisata adalah segala sesuatu yang memiliki keunikan, keindahan dan nilai yang berupa keanekaragaman kekayaan alam, budaya dan hasil buatan manusia yang menjadi sasaran atau tujuan kunjungan wisatawan. Persepsi responden terhadap daya tarik ekowisata di PIM Pekalongan disajikan pada Tabel 3.

Tabel 3. Persepsi terhadap Daya Tarik Ekowisata

\begin{tabular}{|c|c|c|c|c|c|c|c|c|c|}
\hline \multirow{2}{*}{ No. } & \multirow{2}{*}{ Pertanyaan } & \multicolumn{4}{|c|}{ Pengunjung (\%) } & \multicolumn{4}{|c|}{ Masyarakat (\%) } \\
\hline & & 1 & 2 & 3 & 4 & 1 & 2 & 3 & 4 \\
\hline 1. & Keindahan alam/ pemandangan & - & 30 & 48 & 22 & - & 20 & 47 & 33 \\
\hline 2. & Keanekaragaman vegetasi & 3 & 37 & 39 & 21 & - & 20 & 53 & 27 \\
\hline 3. & Keanekaragaman biota & 30 & 39 & 27 & 4 & 7 & 53 & 33 & 7 \\
\hline 4. & Wahana perahu (boat) & 1 & 24 & 53 & 22 & - & - & 47 & 53 \\
\hline 5. & Jogging track & - & 33 & 38 & 29 & - & 13 & 40 & 47 \\
\hline
\end{tabular}

Keterangan:

$1=$ Tidak Baik $\quad 2$ Kurang Baik $\quad 3=$ Baik $\quad 4$ = Sangat $\quad 3 a i k$

\section{Persepsi terhadap Fasilitas/Sarana Prasarana}

Fasilitas/sarana prasarana merupakan salah satu faktor penunjang yang memudahkan pengunjung dalam menikmati objek wisata secara langsung. Untuk mendukung kegitan ekowisata, kawasan wisata memerlukan beberapa sarana dan prasarana untuk pelayanan wisatawan. Sarana dan prasarananya seperti: jalan, restoran, pusat informasi, toilet, dan lain-lain harus dibangun untuk memenuhi kebutuhan wisatawan (Nugraha et al., 2015). Persepsi terhadap fasilitas/sarana prasarana disajikan pada Tabel 4.

Tabel 4. Persepsi terhadap Fasilitas/Sarana Prasarana

\begin{tabular}{clcccccccc}
\hline \multirow{2}{*}{ No. } & \multirow{2}{*}{ Pertanyaan } & \multicolumn{4}{c}{ Pengunjung (\%) } & \multicolumn{4}{c}{ Masyarakat (\%) } \\
\cline { 3 - 10 } & & $\mathbf{1}$ & $\mathbf{2}$ & $\mathbf{3}$ & $\mathbf{4}$ & $\mathbf{1}$ & $\mathbf{2}$ & $\mathbf{3}$ & $\mathbf{4}$ \\
\hline 1. & Tempat parkir & 14 & 54 & 29 & 3 & 3 & 50 & 40 & 7 \\
2. & Gedung PRPM/PIM & - & 24 & 49 & 27 & - & 3 & 53 & 44 \\
3. & Shelter & 2 & 30 & 46 & 22 & - & 7 & 57 & 36 \\
4. & Toilet/WC & 3 & 55 & 35 & 7 & 10 & 50 & 27 & 13
\end{tabular}




\begin{tabular}{llcccccccc} 
5. & Tempat ibadah & 6 & 52 & 42 & - & 13 & 50 & 33 & 4 \\
6. & Jogging track & 7 & 43 & 49 & 1 & - & 67 & 30 & 3 \\
7. & Menara pandang & 31 & 45 & 20 & 4 & 30 & 47 & 17 & 6 \\
\hline
\end{tabular}

Keterangan:

$1=$ Tidak Baik ; $\quad 2$ = Kurang Baik $\quad 3$ = Baik $\quad 4$ = Sangat Baik

\section{Persepsi terhadap Aksesibilitas}

Aksesibilitas merupakan syarat penting untuk mempermudah pengunjung berkunjung ke suatu tempat objek wisata. Syarat yang diperlukan dalam melakukan kunjungan ke suatu objek wisata yaitu jarak yang dekat, kondisi jalan menuju objek wisata, tipe jalan, dan waktu yang diperlukan dari pusat kota (Simanjuntak et al., 2016). Persepsi terhadap aksesibilitas disajikan pada Tabel 5.

Tabel 5. Persepsi terhadap Aksesibilitas

\begin{tabular}{|c|c|c|c|c|c|c|c|c|c|}
\hline \multirow{2}{*}{ No. } & \multirow{2}{*}{ Pertanyaan } & \multicolumn{4}{|c|}{ Pengunjung (\%) } & \multicolumn{4}{|c|}{ Masyarakat (\%) } \\
\hline & & 1 & 2 & 3 & 4 & 1 & 2 & 3 & 4 \\
\hline 1. & $\begin{array}{l}\text { Kondisi jalan menuju } \\
\text { ekowisata }\end{array}$ & 7 & 29 & 47 & 17 & - & 3 & 47 & 50 \\
\hline 2. & Rute jalan & 1 & 19 & 63 & 17 & - & 17 & 43 & 40 \\
\hline 3. & Transportasi umum & 18 & 47 & 34 & 1 & 17 & 57 & 26 & - \\
\hline 4. & $\begin{array}{l}\text { Petunjuk arah lokasi } \\
\text { ekowisata }\end{array}$ & 19 & 45 & 30 & 6 & 7 & 60 & 30 & 3 \\
\hline 5. & Jarak menuju ekowisata & - & 23 & 62 & 15 & - & 7 & 50 & 43 \\
\hline
\end{tabular}

Keterangan:

$1=$ Tidak Baik $; \quad 2=$ Kurang Baik $\quad 3=$ Baik $\quad \quad 4$ Sangat $\quad 3 a i k$

\section{Partisipasi}

\section{Partisipasi Responden dalam Menjaga Lingkungan}

Menurut Elhaq dan Arif (2011), partisipasi adalah keikutsertaan setiap pihak yang terlibat dalam setiap tahapan kegiatan pembangunan. Partisipasi dibagi ke dalam beberapa tahapan, yaitu: tahap pengambilan keputusan; tahap pelaksanaan; tahap menikmati hasil; dan tahap evaluasi

Partisipasi responden dalam menjaga lingkungan pada Kawasan Ekowisata di PIM Pekalongan disajikan pada Tabel 6.

Tabel 6. Partisipasi Responden dalam Menjaga Lingkungan

\begin{tabular}{|c|c|c|c|c|c|c|c|c|c|}
\hline \multirow{2}{*}{ No. } & \multirow{2}{*}{ Pertanyaan } & \multicolumn{4}{|c|}{ Pengunjung (\%) } & \multicolumn{4}{|c|}{ Masyarakat (\%) } \\
\hline & & TS & KS & $\mathbf{S}$ & SS & TS & KS & $\mathbf{S}$ & SS \\
\hline 1. & Coret-coret/vandalisme & 69 & 31 & - & - & 90 & 10 & - & - \\
\hline 2. & Membuang sampah sembarangan & 97 & 3 & - & - & 77 & 33 & - & - \\
\hline 3. & Merusak tanaman & 100 & - & - & - & 93 & 7 & - & - \\
\hline 4. & Merusak sarana-prasarana & 91 & 9 & - & - & 63 & 37 & - & - \\
\hline
\end{tabular}

Keterangan:

$$
\text { TS = Tidak Setuju } ; \quad \text { KS }=\text { Kurang Setuju } ; \quad S=\text { Setuju } ; \quad \text { SS = Sangat Setuju }
$$

\section{Aspirasi Responden dalam Pengembangan Ekowisata}

Aspirasi merupakan kemauan atau dorongan kehendak yang terarah pada tujuan-tujuan tertentu dan dikendalikan oleh pertimbangan akal budi atau harapan serta tujuan untuk keberhasilan pada masa yang akan datang. Aspirasi Responden baik masyarakat maupun pengunjung terhadap pengembangan ekowisata di PIM Pekalongan disajikan pada Tabel 7.

Tabel 7. Aspirasi Responden dalam Pengembangan Ekowisata

\begin{tabular}{|c|c|c|c|}
\hline No. & Aspirasi & Pengunjung & Masyarakat \\
\hline 1. & $\begin{array}{l}\text { Jenis wisata yang menjadi } \\
\text { keunggulan }\end{array}$ & Wisata alam & Wisata alam \\
\hline 2. & $\begin{array}{l}\text { Kendala dalam pengembangan } \\
\text { wisata }\end{array}$ & $\begin{array}{l}\text { Kurangnya fasilitas sarana } \\
\text { rasarana penunjang ekowisata }\end{array}$ & $\begin{array}{l}\text { Kurangnya memperlibatkan } \\
\text { masyarakat sekitar }\end{array}$ \\
\hline 3. & $\begin{array}{l}\text { Peluang dalam pengembangan } \\
\text { wisata }\end{array}$ & $\begin{array}{l}\text { Terbukanya peluang usaha bagi } \\
\text { masyarakat sekitar }\end{array}$ & $\begin{array}{l}\text { Peluang usaha seperti usaha } \\
\text { kuliner }\end{array}$ \\
\hline
\end{tabular}


4. Ancaman yang merugikan ekosistem mangrove
Kawasan yang rentan terhadap abrasi
Kawasan yang rentan terhadap abrasi

\section{Strategi Pengembangan Ekowisata di PIM Pekalongan}

Penyusunan strategi pengembangan ekowisata yaitu dengan menggunakan analisis SWOT. Analisis SWOT didasarkan pada identifikasi faktor strategis yang terdiri dari faktor internal (IFAS) dan faktor eksternal (EFAS) yang didapatkan dari hasil wawancara selama kegiatan penelitian dan pengamatan di lapangan. Faktor internal dan eksternal disajikan pada Tabel 8 dan 9.

Tabel 8. Identifikasi Faktor Strategi Internal

\begin{tabular}{lccc}
\hline Faktor Strategi Internal & \multirow{2}{*}{ Bobot } & Rating & Skor \\
\hline Kekuatan (Strenghts) & 0,125 & 3 & 0,375 \\
\hline 1. Kondisi ekosistem mangrove & 0,106 & 2 & 0,212 \\
2. Keberadaan flora dan fauna di ekosistem mangrove & 0,116 & 3 & 0,348 \\
3. Pemandangan alam yang ditawarkan di ekosistem mangrove & 0,121 & 3 & 0,363 \\
4. Kelayakan ekosistem mangrove untuk dijadikan sebagai kawasan & & \\
$\quad$ ekowisata & 0,113 & 3 & 0,339 \\
5. Pengembangan potensi yang ada di ekosistem mangrove & & \\
\hline Kelemahan (Weaknesses) & 0,100 & 2 & 0,200 \\
\hline 1. Sarana prasarana penunjang yang disediakan di ekosistem mangrove & 0,094 & 3 & 0,282 \\
2. SDM masyarakat lokal untuk pengembangan ekowisata & 0,107 & 2 & 0,214 \\
3. Fasilitas sanitasi yang tersedia (tempat sampah, toilet) & 0,118 & 2 & 0,236 \\
4. Akses menuju ekosistem mangrove Kelurahan Kandang Panjang & 1 & & 0,257 \\
\hline Total & & & \\
\hline
\end{tabular}

Tabel 9. Identifikasi Faktor Strategi Eksternal

\begin{tabular}{|c|c|c|c|}
\hline Faktor Strategi Eksternal & \multirow{2}{*}{ Bobot } & \multirow{2}{*}{ Rating } & \multirow{2}{*}{ Skor } \\
\hline Peluang (Opportunities) & & & \\
\hline 1. Jenis wisata alam yang ditawarkan di Kelurahan Kandang Panjang & 0,165 & 2 & 0,330 \\
\hline 2. Trend perkembangan minat wisata alam pengunjung/wisatawan & 0,177 & 3 & 0,531 \\
\hline $\begin{array}{l}\text { 3. Peran pemerintah Kota Pekalongan dalam pengembangan ekosistem } \\
\text { mangrove }\end{array}$ & 0,178 & 3 & 0,534 \\
\hline 4. Partisipasi lembaga non pemerintah terhadap kegiatan pariwisata & 0,166 & 3 & 0,498 \\
\hline \multicolumn{4}{|l|}{ Ancaman (Threats) } \\
\hline 1. Kawasan yang rentan terhadap abrasi & 0,164 & 2 & 0,328 \\
\hline 2. Sampah yang dihasilkan oleh pengunjung/wisatawan & 0,150 & 3 & 0,450 \\
\hline Total & 1 & & 2,671 \\
\hline
\end{tabular}

\section{Analisis SWOT}

Penggabungan matriks SWOT yaitu didapatkan beberapa alternatif strategi S-O, strategi S-T, strategi W-O dan strategi W-T. Hasil SWOT pengembangan ekowisata di PIM Kelurahan Kandang Panjang Pekalongan dapat dilihat pada Tabel 10 .

Tabel 10. Hasil Matriks SWOT

\begin{tabular}{|c|c|c|}
\hline 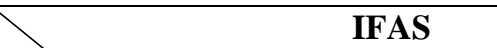 & Kekuatan (Strengths) & Kelemahan (Weaknesses) \\
\hline EFAS & $\begin{array}{l}\text { Kondisi ekosistem mangrove } \\
\text { yang baik } \\
\text { Adanya flora dan fauna } \\
\text { Pemandangan alam yang } \\
\text { indah dan asri } \\
\text { Layak menjadi kawasan } \\
\text { ekowisata } \\
\text { Adanya potensi yang dapat } \\
\text { dikembangkan }\end{array}$ & $\begin{array}{l}\text { Sarana prasarana belum lengkap } \\
\text { Keterbatasan SDM Masyarakat } \\
\text { sekitar } \\
\text { Kurangnya fasilitas sanitasi } \\
\text { Akses menuju ekowisata yang } \\
\text { sulit diakses oleh angkutan } \\
\text { umum }\end{array}$ \\
\hline Peluang (Opportunities) & Strategi S-O & Strategi W-O \\
\hline $\begin{array}{l}\text { Belum adanya ekowisata sejenis } \\
\text { Meningkatnya jumlah } \\
\text { pengunjung }\end{array}$ & $\begin{array}{l}\text { Pengembangan ekowisata } \\
\text { dengan konsep pelestarian } \\
\text { ekosistem serta melakukan }\end{array}$ & $\begin{array}{l}\text { Peningkatan pemberdayaan } \\
\text { masyarakat sekitar dalam } \\
\text { mengoptimalkan fasilitas kawasan }\end{array}$ \\
\hline
\end{tabular}




\begin{tabular}{|l|l|l|}
\hline $\begin{array}{l}\text { Dukungan dari Pemerintah untuk } \\
\text { kegiatan pengembangan } \\
\text { Banyak didukung oleh lembaga } \\
\text { non pemerintah }\end{array}$ & $\begin{array}{l}\text { koordinasi dengan Pemerintah } \\
\text { Daerah }\end{array}$ & ekowisata \\
\hline Ancaman (Threats) & \multicolumn{1}{|c|}{ Strategi S-T } & \multicolumn{1}{c|}{ Strategi W-T } \\
\hline - Kawasan yang rentan terhadap \\
$\begin{array}{l}\text { abrasi } \\
\text { Sampah yang dihasilkan } \\
\text { pengunjung }\end{array}$ & $\begin{array}{l}\text { Menjaga ekosistem mangrove } \\
\text { dengan cara mengefektifkan } \\
\text { rehabilitasi dan penegakan } \\
\text { peraturan perlindungan } \\
\text { mangrove }\end{array}$ & $\begin{array}{l}\text { Meningkatkan fasilitas/sarana } \\
\text { prasarana yang dapat digunakan } \\
\text { untuk meminimalkan dampak dari } \\
\text { abrasi }\end{array}$ \\
\hline
\end{tabular}

\section{Penentuan Alternatif Strategi}

Alternatif strategi pengembangan berhasil didapatkan, maka selanjutnya jumlah skor yang berasal dari keterkaitan masing-masing strategi diurutkan berdasarkan nilai terbesar untuk dijadikan alternatif strategi dalam pengembangan ekowisata di PIM Kelurahan Kandang Panjang Pekalongan. Penentuan alternatif strategi disajikan pada Tabel 11 berikut.

Tabel 11.Alternatif Strategi Pengembangan

\begin{tabular}{l|l|c|c}
\hline Alternatif Strategi & Keterkaitan & Nilai & Rangking \\
\hline $\begin{array}{l}\text { Strategi S-O } \\
\begin{array}{l}\text { Pengembangan ekowisata dengan konsep pelestarian } \\
\text { ekosistem serta melakukan koordinasi dengan Pemerintah } \\
\text { Daerah }\end{array}\end{array}$ & $\begin{array}{l}\text { S1, S2, S3, S4, } \\
\text { S5, O1, O2, } \\
\text { O3, O4 }\end{array}$ & 3,530 & I \\
\hline $\begin{array}{l}\text { Strategi W-O } \\
\begin{array}{l}\text { Peningkatan pemberdayaan masyarakat sekitar dalam } \\
\text { mengoptimalkan fasilitas kawasan ekowisata }\end{array}\end{array}$ & $\begin{array}{l}\text { W1, W2, W3, O1, O2, } \\
\text { O3, O4 }\end{array}$ & 2,825 & II \\
\hline $\begin{array}{l}\text { Strategi S-T } \\
\begin{array}{l}\text { Menjaga ekosistem mangrove dengan cara mengefektifkan } \\
\text { rehabilitasi dan penegakan peraturan perlindungan } \\
\text { mangrove }\end{array}\end{array}$ & $\begin{array}{l}\text { S1, S2, S3, S4, } \\
\text { S5, T1, T2 }\end{array}$ & 2,415 & III \\
\hline $\begin{array}{l}\text { Strategi W-T } \\
\text { Meningkatkan fasilitas/sarana prasarana yang dapat }\end{array}$ & $\begin{array}{l}\text { W1, W2, W3, } \\
\text { digunakan untuk meminimalkan dampak dari abrasi }\end{array}$ & 1,710 & IV \\
\hline
\end{tabular}

\section{KESIMPULAN}

Potensi daya tarik ekowisata mangrove di PIM Kelurahan Kandang Panjang Pekalongan yaitu keanekaragaman spesies mangrove, asosiasi biota yang ada didalamnya, serta sarana prasarana.

Persepsi responden mengenai daya tarik dan aksesibilitas tergolong baik, sedangkan persepsi mengenai fasilitas tergolong kurang baik. Partisipasi responden dalam menjaga lingkungan sekitar juga tergolong baik karena sebagian responden tidak setuju dengan adanya tindakan negatif terhadap lingkungan. Aspirasi responden yaitu mengenai pengadaan fasilitas/sarana prasarana.

Strategi pengembangan ekowisata mangrove di PIM yaitu: pengembangan ekowisata dengan konsep pelestarian ekosistem serta melakukan koordinasi dengan Pemerintah Daerah; peningkatan pemberdayaan masyarakat sekitar dalam mengoptimalkan fasilitas kawasan ekowisata; menjaga ekosistem mangrove dengan cara mengefektifkan rehabilitasi dan penegakan peraturan perlindungan mangrove; dan meningkatkan fasilitas/sarana prasarana yang dapat digunakan untuk meminimalkan dampak dari abrasi

\section{UCAPAN TERIMAKASIH}

Penulis menyampaikan terimakasih kepada semua pihak yang telah memberikan bantuan dalam penulisan jurnal ilmiah ini.

\section{DAFTAR PUSTAKA}

Agussalim, A. dan Hartoni. 2014. Potensi Kesesuaian Mangrove sebagai Daerah Ekowisata di Pesisir Muara Sungai Musi Kabupaten Banyuasin. Jurnal Maspari. 6 (2) : 148-156. 
Chadijah, A., Y. Wadritno dan Sulistiono. 2013. Keterkaitan Mangrove, Kepiting Bakau (Scylla olivacea) dan Beberapa Parameter Kualitas Air di Perairan Pesisir Sinjai Timur. Jurnal Ilmu Perikanan. 1 (2) : 116122.

Elhaq, I. H. dan A. Satria. 2011. Persepsi Pesanggem mengenai Hutan Mangrove dan Partisipasi Pesanggem dalam Pengelolaan Tambak Mangrove Ramah Lingkungan Model Empang Parit. Jurnal Transdisiplin Sosiologi, Komunikasi, dan Ekologi Manusia. 5 (1) : 97-103.

Haryanto, J. T. 2014. Model Pengembangan Ekowisata dalam Mendukung Kemandirian Ekonomi Daerah Studi Kasus Provinsi DIY. Jurnal Kawistara. 4 (3) : 271-286.

Murianto. 2014. Potensi dan Persepsi Masyarakat serta Wisatawan terhadap Pengembangan Ekowisata di Desa Aik Berik, Lombok Tengah. Jurnal Jumpa. 1 (1) : 43-64.

Nugraha, B., I. S. Banuwa dan S. Widagdo. 2015. Perencanaan Lanskap Ekowisata Hutan Mangrove di Pantai Sari Ringgung Desa Sidodadi Kecamatan Padang Cermin Kabupaten Pesawaran. Jurnal Sylva Lestari. 3 (2) : 53-66.

Rosadi, P., E. Roslinda dan Wahdina. 2015. Potensi Daya Tarik Riam Berawat'n untuk Wisata Alam di Dusun Melayang Desa Sahan Kecamatan Seluas Kabupaten Bengkayang. Jurnal Hutan Lestari. 3 (3) : 363 373.

Saifullah dan N. Harahap. 2013. Strategi Pengembangan Wista Mangrove di "Blok Bedul" Taman Nasional Alas Purwo Kabupaten Banyuwangi Jawa Timur. Journal of Indonesian Tourism and Development Studies. $1(2): 79-86$.

Simanjuntak, C. R., P. Patana dan K. S. Hartini. 2016. Analisis Kelayakan dan SWOT Objek Wisata Pemandian Alam Taman Rekreasi Gotong Royong Indah di Desa Hulu, Kecamatan Pancurbatu, Kabupaten Deli Serdang, Provinsi Sumatera Utara. Peronema Forestry Science Journal. 5 (1) : 176-183.

Sugiyono. 2012. Metode Penelitian Kuantitatif Kualitatif dan R\&D. Alfabeta. Bandung. 2013. Metode Penelitian Kuantitatif Kualitatif dan R\&D. Cetakan ke-19. Alfabeta. Bandung.

Undang-Undang Republik Indonesia Nomor 10 Tahun 2009 tentang Kepariwisataan. 